\title{
TWO CENTURIES OF ECONOMIC GROWTH: LATIN AMERICA AT ITS BICENTENNIAL CELEBRATION
}

\section{RAIMUNdo Soto* \\ Felipe Zurita**}

\begin{abstract}
On December 2010, five research teams gathered in Santiago, Chile, to discuss the growth experiences of Argentina, Chile, Colombia, Mexico and Venezuela since independence from Spain was declared in 1810. The five teams answered an invitation from the editors of the Latin American Journal of Economics to explain why these countries' growth experiences lag so far behind those of the developed world, and at the same time, why their trajectories have been so dissimilar. This paper serves as an introduction to the special issue, characterizing the patterns of growth in Latin America, and discussing the teams' answers.
\end{abstract}

\section{JEL Classification: O4}

Keywords: growth, Latin America, bicentenary

\section{INTRODUCTION}

The papers in this volume deal with the economic experience of the five Latin American countries that declared independence from Spain in 1810: Argentina, Chile, Colombia, Mexico and Venezuela. Independence, nevertheless, was not achieved until the end of the decade, when Spanish troops were finally defeated in Argentina and Chile (1818), Colombia (1819), and in Mexico and Venezuela (1821). As of 2010, these five economies comprised around $45 \%$ of total GDP in Latin America and $42 \%$ of population and represented the most developed of all countries in the region. Absent from this group is Latin America's giant economy-Brazil—which gained independence from Portugal only in 1822.

Year 2010 marked two centuries of political and economic independence in these countries. The occasion invited social scientists to make a long-run assessment of development in Latin America and address the underlying question of why economic growth has been mediocre, elusive,

\footnotetext{
* Instituto de Economía, Pontificia Universidad Católica de Chile and Dubai Economic Council. E-mail address: rsoto@dec.org.ae

** Instituto de Economía, Pontificia Universidad Católica de Chile. E-mail address: fzurita@uc.cl
} 
and highly unstable, while developed countries and the emerging Asian economies have been able to deliver, to a large extent, the promise of material welfare for the vast majority of their inhabitants. This project is the response to such opportunity.

The challenge to the participants in this project was to move beyond the mere account of facts and anecdotes into the rigorous testing of well-founded economic theories. Economics in Latin America has a long history of explanations for its economic phenomena, a history in which rigorous testing of hypothesis is largely absent and data is merely used for illustrative purposes. As aptly expressed in one of the papers in this volume, the statistical analysis of past data is as valuable as history repeats itself, but to move forward one needs to test a theory. Using different, ingenuous and novel theoretical frameworks the authors of the papers in this volume set out to discuss the salient aspects of development (or lack thereof) of each country: taken as a whole they provide a compelling diagnosis of Latin America's development path and, implicitly, they show us the type of policies our countries require to foster sustainable economic growth and higher welfare levels.

Undoubtedly, the explanations provided in these five papers are a significant contribution to our understanding of sustainable development and the role of economic policies. At the same time, these papers provide only partial answers to the pressing needs of Latin American development. But as such, they are solid stepping stones for future research.

The rest of this paper is organized as follows. Section 2 gives an overview of the last two centuries in Latin America. Section 3 discusses common aspects of the conclusions in the other five papers in this issue. Section 4 concludes.

\section{A QUICK LOOK AT LATIN AMERICA's First TWO CENTURIES SINCE INDEPENDENCE: THE DISAPPOINTING FACTS}

Economic development after independence in these five countries, as well as in the rest of Latin America, has been rather disappointing (Andre Hofman, 2000; Dominique Hachette, 2011). Economic growth has been slow, wealth inequality substantial and economic and political instability pervading. Progress has undoubtedly been made: as of 2010 these five countries were classified as upper-middle income economies 
by the World Bank (2011). However, at times such progress has been too slow to provide lasting solutions to the pressing demands of our societies thus fueling social unrest and political turmoil. At others, progress has been fast enough to raise hopes, only to show at later stages that it was indeed unsustainable and ephemeral. Instability in economic growth as well as in political life is a defining trait of Latin America's development. Disappointment with economic growth in Latin America is amplified by the successful development of East Asian economies in the 1980s and 1990s and, more recently, China (World Bank, 2001).

At the times of independence, nevertheless, Latin American economies were not in disadvantage to achieve economic development. In Table 1 it can be seen that, according to estimates by Angus Maddison (2006), as of 1820 Chile and Mexico had per-capita income levels that were around one half that of European economies and the US. Venezuela lagged slightly behind. Data for Colombia and Argentina are not available but one could safely assume that income levels in Colombia were not markedly different to the other three Latin American economies, while that of Argentina is estimated as equivalent to the US in James Coatsworth (2008). In fact, income levels in these Latin American countries seem to have been typical for non-European economies: Maddison estimates indicate that all Asian economiesfrom Malaysia to India and China-had income levels very similar to Chile and Mexico and also that the world average was not significantly different. The very low income level of Singapore reflects that it had only been founded in 1819 by Thomas Raffles and amounted to little more than a British overseas trading post.

Historians tend to agree that there was a decline in income per-capita in Latin American countries relative to Europe between 1750 and 1850 (Coatsworth, 2008) although estimates of economic activity are scarce and imprecise. Independence would then locate at the end of a declining period. Explanations for such decline point mainly at the poor quality of institutions: Iberian colonialism failed to create dynamic societies that could independently generate technological or organizational innovation. Stanley L. Engerman and Kenneth L. Sokoloff (1997) pose that institutions designed for the exploitation of Latin America's natural resources (large slave plantations in the tropics and large grain and cattle haciendas elsewhere) led to wealth concentration and unequal societies in which settler elites exploited the majority indigenous or imported slave populations. 
These colonial arrangements - which persisted long past the end of colonial rule - were not amenable to competition and productive investment as they protected the property rights of elites, but denied such protections to powerless subordinate classes. Daron Acemoglu, Simon Johnson and James A. Robinson (2001) deny the importance of natural resource endowments and pose that inequality stem from the enactment of extractive institutions by settler elites designed to dominate large populations of native or African descent. Again, these "extractive institutions" deliberately excluded majorities from power and failed to protect their property and human rights, thus leading to low investment in human and physical capital. Matthew Lange, James Mahoney and Matthias vom Hau's (2006) theory points at the differences between colonial rulers, whereby institutions stemming from "mercantilism" in Spain were inimical to growth as opposed to those arising from "liberalism" in Britain. Accordingly, major institutional or policy constraints that inhibited economic growth in both Spain and its colonies include the burdensome Spanish legal system, the political risk of confiscation or other losses, the slow rate of human capital formation, and anti-trade policies.

Coatsworth (2008) correctly points out that these explanations do not match the data and are inadequate to explain the slow growth of the first fifty years after independence for a variety of reasons. First, income inequality in Latin America was not different to that in North America. Second, productivity differences between the richest and poorest Latin American colonies in the early 1800s were nearly as great as for the richest and poorest regions of the entire world and seem to be entirely unrelated to subsequent economic success or failure. Third, because Latin American countries were not in disadvantage in 1820, it seems that institutions mattered for development only after independence. Fourth, and more importantly, there is little evidence that settler elites were able to dominate colonial administrations, control policy making, or shape institutions just as they pleased.

Independence did not necessarily bring political stability to Latin American countries, with the exception of Chile where a unitary republic was in place already by 1830 . In some countries - such as Argentina and Colombia - internal conflicts were not solved until around 1860. In other countries, internal conflicts were reinforced by territorial disputes with neighboring countries (e.g., Mexico) that were not solved until around the same time. 
Table 1. Real GDP per capita

(Geary-Khamis International Dollars of 1990)

\begin{tabular}{|c|c|c|c|c|c|}
\hline & 1820 & 1870 & 1920 & 1970 & 2010 \\
\hline Argentina & & 1,311 & 3,473 & 7,302 & 11,886 \\
\hline Chile & 694 & 1,290 & 2,768 & 5,231 & 13,490 \\
\hline Colombia & & & 1,255 & 3,094 & 6,445 \\
\hline Mexico & 759 & 674 & 1,823 & 4,320 & 7,732 \\
\hline Venezuela & 460 & 569 & 1,173 & 10,672 & 9,599 \\
\hline Europe* & 1,234 & 2,080 & 3,313 & 10,925 & 21,436 \\
\hline Spain & 1,008 & 1,207 & 2,212 & 6,319 & 18,091 \\
\hline USA & 1,257 & 2,445 & 5,552 & 15,030 & 30,543 \\
\hline China & 600 & 530 & & 778 & 8,931 \\
\hline India & 533 & 533 & 635 & 868 & 3,397 \\
\hline South Korea & 600 & 604 & 1,092 & 2,167 & 20,771 \\
\hline Thailand & 570 & 608 & & 1,694 & 9,088 \\
\hline Taiwan & 550 & 550 & 861 & 2,537 & 24,484 \\
\hline Hong Kong & 615 & 683 & & 5,695 & 32,537 \\
\hline Malaysia & 603 & 663 & 1,110 & 2,079 & 10,515 \\
\hline Singapore & 83 & 682 & & 4,439 & 28,090 \\
\hline World & 666 & 870 & & 3,726 & 6,874 \\
\hline
\end{tabular}

Source: Maddison, Contours of the World Economy 1-2030 AD, for the period 1820-2006 and World Bank, World Development Indicators, for the period 2007-2010.

Note: $(*)$ includes Austria, Belgium, Denmark, Finland, France, Germany, Italy, Netherlands, Norway, Sweden, Switzerland, and the UK.

By 1870, half a century after independence, these five Latin American economies had entered a period of political control of internal affairs, enacted significant liberalization reforms and, benefiting from favorable external conditions, resumed sustained growth. European countries and the US, in the meantime, had taken full advantage of industrialization and progressed to the point of doubling income per capita to around US\$ 2,000. Some Latin American countries-Argentina and Chilemanaged to keep pace with advanced economies in terms of relative income levels, while Mexico and Venezuela remained as stagnant as all Asian economies (the significant exception is Singapore that had already caught up with regional levels). Interestingly, evidence for Spain in Table 1 indicates it performed less dynamically that its ex-colonies and its income level grew very slowly, reaching around one half of that in the US and not significantly different of those in Argentina and Chile. 
One hundred years after effective independence, economic growth in Latin American economies continued steady but countries started to diverge. On one hand, Argentina seemed to be on a pace of fast development and had reached income levels as high as the main European countries and around 50\% higher than Spain. Vigorous economic growth in Chile, on the other hand, started to lose steam after 1900 and could not follow pace with the rapid growth of Argentina, managing to achieve income levels only around 25\% higher than Spain but still well below Europe or the US levels. Mexico experienced accelerated growth since 1870 but its initial low income level only allowed the economy to catch-up to around $50 \%$ of European standards. Likewise, Venezuela and Colombia which have stayed initially behind managed to grow systematically but not to close the gap vis-à-vis Europe and the US.

As discussed by all papers in this volume, the Great Depression of the 1930s marked a decisive change in economic policy and long run growth. The negative shock was very significant in Chile, Mexico and Venezuela with per-capita GDP dropping in the range of $20 \%$ to $30 \%$, but it affected less Argentina and Colombia. Figure 1 plots the cyclical component of GDP per-capita defined as the deviations from trend (the latter obtained as customary using Hodrick and Prescott's filter with the smooth parameter set at 100). It can be seen that, in addition to the Great Depression downturn, Argentina and Colombia had been also affected by negative shocks in the early 1920s resulting from the post-World War I adjustment. In response to the decline in exports and protracted recession, Latin American economies closed their economies and embarked in massive programs of public investment in support of import substitution and the development of domestic manufacturing industries.

The import substitution experiment ran for about four decades in all economies but Venezuela. By the end of the 1960s it had ran out of momentum and the numerous distortions it induced had become a heavy burden for Latin American economies. In addition, the massive restructuring of the economies under the import substitution strategy led to mounting social tensions that expressed in increasing political instability (Edwards, 2009). Between 1930 and 1970, income per-capita grew at around 1.5\% per year in Argentina, Chile, Mexico and Colombia, a very similar rate to that of the previous fifty years. However, the post-World War II period was one of accelerated growth in the world (over 2\% per year in the period 1950-1970) and, in particular, in Europe and the US (both with annual rates of $2.6 \%$ on average). Real income 
Figure 1. Economic cycles

(deviations of log real GDP per capita from HP-trend)

Argentina

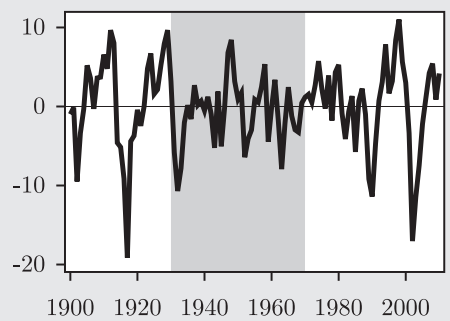

Colombia

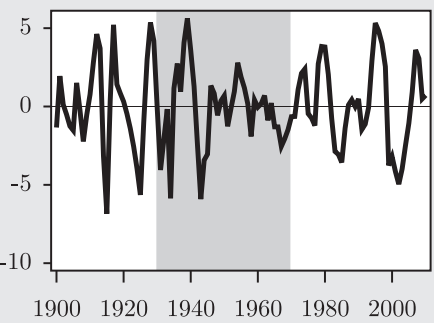

Chile

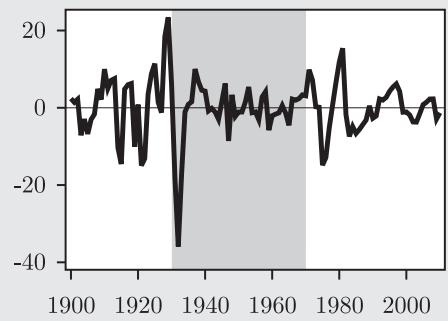

Mexico

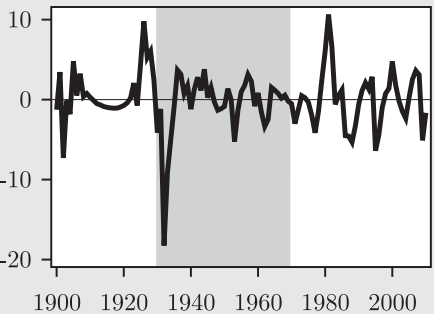

Venezuela

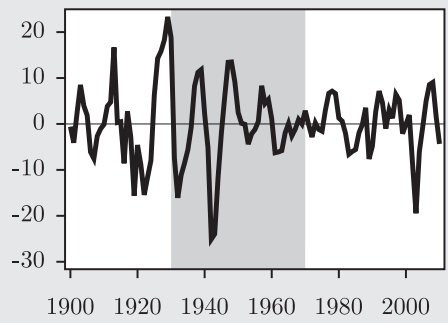

per-capita tripled in advanced economies while it only doubled in these four Latin American countries: consequently, while in 1920 income percapita in these Latin American countries was on average at around 70\% of European levels, by 1970 it had reduced to only $45 \%$.

Slow growth during the import substitution experiment was, nevertheless, accompanied by significantly lower levels of volatility in Argentina, Chile and Mexico and, after 1950, also in Colombia. The papers in 
this volume also document the slow growth in labor productivity that characterizes the period of import substitution. And while economic cycles may have ameliorated, increasing instability showed in other dimensions of the economy. In particular, the main Latin American countries in the second half of the $20^{\text {th }}$ century became the epitome of chronically high inflation and structural massive unemployment.

Venezuela, on the other hand, benefited enormously from the discovery and extraction of oil in Maracaibo in 1922 and became the richest economy of the region. By 1929, Venezuela was the second largest oil producing country (behind only the United States) and the largest oil exporter in the world. With such a dramatic development of the industry, income levels expanded extraordinarily but as the oil sector began to dominate all other economic sectors in the country other industries receded dramatically. The paper by Bello, Blyde and Restuccia in this volume documents how substantial oil revenues were initially used to build infrastructure and basic industries thus fostering growth, but later massively misused hampering economic growth and productivity gains.

While Latin American countries were enthusiastically embarking on import-substitution policies, East Asian countries chose the exact opposite strategy (World Bank, 2001). And while in Latin America economic growth languished, countries such as Hong Kong and Singapore managed to grow at astonishing rates. Table 1 provides the evidence of such remarkable growth: by 1970 both state-economies had already caught up with Latin American countries, while Korea, Malaysia, and Taiwan were already taking off.

In all papers in this volume, the authors find evidence of a significant break in trend in economic growth during the 1970s. The nature of such break, however, is not common to all economies. On one hand, Chile successfully implemented a series of pro-market reforms and managed to grow at much faster pace than during the import-substitution years: between 1970 and 2010, the economy grew at annual rates over $2.2 \%$ and closed significantly the gap with European countries. In fact, as of 2010 per-capita income in Chile had reached around $75 \%$ of that in Spain, a country that had made a complete turnaround in performance to fully embrace European standards. In Mexico, similar reforms were enacted but their impact has been less significant. On the other hand, the break in trend for other economies has been quite negative, in particular for Argentina and Venezuela, which sloped into economic collapse despite the very favorable external conditions they enjoyed. 
Income per capita in Argentina expanded quite slowly at $0.9 \%$ per year and the economy has experienced three hyperinflations and two major external crises (1989 and 2001). In Venezuela, income per capita declined in absolute terms. In Colombia and Mexico, the sustained growth of the import-substitution strategy gave way to a long and protracted stagnation, in particular in the "lost decade" of the 1980s.

The disillusion with economic growth and development strategies in Latin America is amplified by the contrasting experiences of East Asian economies, first, and India and China more recently. The last column in Table 1 presents the evidence: by 2010, East Asian tigers had income levels well above Latin American countries and emerging economies had already closed the gap. Early birds, such as Hong Kong and Singapore, had already achieved or surpassed the income levels of Europe and the US. Even backward economies of the 1970s such as China and Thailand had already advanced to the level of Mexico and Venezuela.

The dismal performance of most Latin American countries after the 1970s is puzzling, in particular vis-à-vis other emerging economies. The contrast of Chile's experience vis-à-vis Argentina or Venezuela indicates that apparently there is no common cause. However, as the papers in this volume indicate, economic policy seems to have played a major role.

\section{INSIGHTS FROM FIVE DISSIMILAR TRAJECTORIES}

Methodologically, all papers in this volume look at the development process through the glass of a standard Solow-type model with exogenous growth, namely, models where gross domestic product (GDP) can be expressed as:

$$
Y_{t}=A_{t} K_{t}^{\alpha} L_{t}^{1-\alpha}
$$

where $K_{t}$ is capital, $L_{t}$ labor and where $A_{t}$ is total factor productivity (TFP). Economic growth would be, then, the result of capital accumulation, expansions in the use of manpower, and changes in productivity, i.e., improvements in the efficiency of use of such resources. In general, the latter responds to changes in the technology that is available in worldwide markets - whose long-run trend growth is customarily assumed to be constant in long-run analysis - as well as changes in domestic elements such as institutions, government policies, and long-lasting initial conditions (location, natural resource, etc.). 
Once taken into account the contribution of capital and labor, the papers concentrate in analyzing deviations of TFP growth from that long-run trend. While each of the papers focuses on different aspects of the development path in each economy, a different time period, or a different idiosyncratic fact, there is a remarkable commonality among studies: they are all able to associate periods of productivity slowdown or stagnation to broad economic policies.

\subsection{Argentina: Fiscal irresponsibility}

Francisco Buera, Gastón Navarro and Juan Pablo Nicolini discuss the case of Argentina. They start by decomposing the evolution of real per-capita GDP into trend and cyclical components. An annual growth rate in per-capita GDP of around 1.2\% is considered by the authors as a reasonable approximation to the long-run trend of the economy and is also consistent with Maddison's estimates in Table 1. From the volatility of the cyclical component, they identify three distinctive periods in the economic history of the country (in concordance with our Figure 1). The first one starts in 1885 and ends with the unveiling of the Great Depression in 1930. The second period, which is characterized by much lower volatility, ends in 1974 while the third one, which comprises the last 35 years, shows a return to the higher volatility levels of the period 1885-1930. Although the differences in volatility of these three periods may be of importance (for example, Does increased volatility reduce growth?), they are not thoroughly explored in this paper.

The authors prefer to concentrate on the basic insight of the paper, namely, that there is quantitative and qualitative evidence of a significant break in the trend of GDP after 1974 and that this phenomenon is largely the result of fiscal mismanagement. Using a calibrated Solow-type growth model, they show that economic growth in Argentina in the period 1950-1974 is congruent with a calibrated economy in which total factor productivity (TFP) grows at around $1.1 \%$ per year. However, after 1974 the data can only be replicated if the model is simulated from 1950 onwards with zero growth in TFP. In other words, per-capita growth in Argentina after 1974 has been so low that its current situation is the same to what could have been achieved if there had been no productivity growth whatsoever in the last 50 years. The economic development of Argentina, accordingly, has largely been the result of factor accumulation. 
Argentina's break in trend is not unique and it has been documented before for 12 Latin American economies (Andres Solimano and Raimundo Soto, 2006). What sets apart this paper from the previous literature is that it provides a causal economic explanation for the phenomenon. Buera et al. (2011) use the simple mechanics of Thomas Sargent's (1983) model of government financing to show how in periods when the Argentinean government had access to financing, it had inevitably borrowed beyond what was sustainable and, once loans were no longer available, the government had defaulted and the economy had gone through a costly and lengthy period of adjustment. Crisis years are those where fiscal deficits have reached peak levels. A government without recourse to loans is forced to default. But was the Argentinean government finance-constrained at the times of crisis? As discussed by the authors, the discipline of Sargent's model indicates the need to consider not only actual debt levels but also contingent debts when discussing government financing. In particular, contingent debts arose as a result of deposit guarantees in the financial sector and exchange rate insurance. When such adjustment is made, it becomes clear that the Argentinean government was very limited in access to financing precisely in those years when crises happened. Fiscal mismanagement produced large fiscal deficits that, inevitably, went beyond the financing capacity of the government. In turn, this forced the government to default on its debt and monetize the deficits, leading to hyperinflation in 1975, 1985 and 1989 and to massive wealth expropriation in 2001.

\subsection{Chile: Import substitution}

The paper by Rodrigo Fuentes on Chile also points out to the existence of "structural breaks," i.e., abrupt changes in the contribution of the different determinants of long-run growth as a result of shocks that can have long-lasting effects. However, contrary to the other studies, he benefits from the availability of long series on the major macroeconomic variables covering the period 1810-2010. Therefore, the author is able to undertake formal tests for the hypotheses of trend breaks and confirm the observations made by other authors of a significant break in GDP trend in 1929 - undoubtedly related to the Great Depression and the ensuing import-substitution strategy - and also in the early 1970s. Fuentes notices that after 1929 the Chilean economy moved on a very different path from that of the period 
1820-1930. Contrary to the cases of Argentina and Colombia, the Great Depression hit Chile very hard: the author suggests that percapita income in Chile did not return to the path predicted by its pre-1930 economic trajectory but until the early 1990s.

Undoubtedly, the reasons for such a long period of stagnation ought to lie beyond the obviously transitory effects of the depression. Fuentes develops a formal theory of economic activity that, under mild assumptions, provides a rigorous framework to test for the presence of such shocks. He finds that the three sub-periods roughly correspond to those in Figure 1. Notably, long-run growth in the period 1930-1971 is slightly higher than that of the period 1830-1930 and one would be tempted to claim that the import-substitution strategy paid Chile dearly. Yet, the dismantling of such strategy and the ensuing boost to private entrepreneurship allowed Chile to expand economic growth at unprecedented levels, comparable to that in East Asian economies. This, according to the author, explains the significant catch-up of Chile's economy.

It is interesting to notice that, while in Argentina and Venezuela government policies are at the root of their dismal economic performance since the mid-1970s, Chile portrays the exactly opposite phenomenon. Policy reforms enacted since 1975 and consolidated in the 1980s and 1990s are, according to Fuentes, the main reason for the turnaround of the Chilean economy. In particular, he assigns a key role to international trade as a catalyst for foreign direct investment and innovation, exactly the opposite story as that of Argentina and Venezuela. But international trade has actually a second but very important role: foreign trade - in particular on natural resources - has been a major source of tax revenue.

Indeed, in Fuentes' analysis, the two structural breaks are no longer present in the data after controlling for openness-related variables and government expenditure. This finding hints at those policies as major determinants of deviations in TFP growth from the (catching up) long run trend.

\subsection{Colombia's protracted backwardness}

Álvaro Riascos discusses the notorious "textbook" case of Colombia. He shows that Colombia's development history can be divided in two stages. The first, covering most of the $1800 \mathrm{~s}$, corresponds to 
the classical Malthusian development stage where growth is driven primarily by factor accumulation (land and labor) and largely characterized by the absence of productivity gains. As expected, zero TFP growth implies a subsequent steady decline of per-capita GDP as compared to the levels of the industrialized world. The second stage, starting about 1910, is characterized by a catching up process of the Solow kind where productivity gains are a significant contributor to sustained economic growth. However, the catch-up phase seems to be very slow, as per capita GDP in Colombia is still about a quarter of that of the UK.

Riascos' (2011) analysis points towards productivity as the main source of differences. Contrary to other papers in this literature, he extends Gary Hansen and Edward Prescott's (2002) model which allows key macroeconomic variables to be endogenously determined (e.g., capital and TFP) thus bypassing the lack of data that is pervasive when testing long-run theories of economic growth in Latin America. The author calibrates the model to the Colombian data using as benchmark the UK in its Malthusian period (i.e., pre 1840). In order to match the data, initial productivity levels in Colombia had to be around one third of those observed in the UK. That is, since independence Colombia had a significant "technological backwardness" relative to the developed economies. Such backwardness made unprofitable an early (endogenous) switch to Solow-type growth: had productivity differences been lower, Colombian industrialization would have taken place before 1910. Interestingly, after 1910 Colombia has been unable to catch up with the UK income levels indicating the existence of technological differences also in the period of TFP-driven economic growth.

While useful, the Hansen and Prescott model cannot provide an explanation for the initial backwardness of Colombia or the lack of significant catch-up effects after 1910. Riascos reviews the explanations provided by researchers in other papers and is able to discard several of them on the basis that they are unlikely related to TFP levels or dynamics. However, he is able to link, albeit anecdotally, TFP levels with the comparatively dismal levels of education in Colombia in the early 1920s. Likewise, he assigns importance to the protracted civil conflict and their deleterious effect on institutions as likely causes of Colombia's retardation. 


\subsection{Venezuela: Barriers to free enterprise}

Venezuela's case differs from the other four economies in many aspects. First and foremost, Venezuela has vast oil reserves. Mexico is the only other oil exporter but its share in exports and economic activity has been less significant. Second, the import-substitution strategy (ISS) was implemented much later and with different intensity in Venezuela vis-à-vis Argentina, Chile, Colombia and Mexico. In the latter, the ISS started to take shape in 1950s but had exhausted herself by the mid 1970s. In Venezuela, it gained momentum only after the nationalization of gas and oil industries in the mid 1970s, became the dominant actor in economic life in the 1980s and it has been furthered in the last decade.

As discussed by Omar Bello, Juan Blyde and Diego Restuccia, following a period of stagnation that comprised most of the 19th century, Venezuela achieved extraordinary growth after the 1920s as the result of the development of the oil industry. Initially, the government used Venezuela's newly found wealth to invest in infrastructure and to finance an ambitious program of investment in key industries such as electricity and coal. Tax revenues on foreign-owned oil companies provided the government with the necessary cash-flow for these projects. This initial stage of government-financed development gave way in the mid 1970s to full-fledged government intervention in the economy after oil companies were nationalized. Additional massive revenues began to flow to the government coffers with the sustained increase in oil prices in the late 1970s and 1980.

Contrary to other Latin American countries that had already started reforms, government intervention in the Venezuelan economy increased systematically after 1975. By the early 1980s, the government controlled $80 \%$ of investment and around $30 \%$ of GDP. The result of this massive intervention is scrutinized in detail by Bello et al. (2011) using a growth accounting method and the US economy as benchmark. Needless to say, the US economy is a tough comparator for any country. Nevertheless, the authors show that by 1958 Venezuela had an income per-capita which was $82 \%$ of that of the US and that the difference was not the result of it being less efficient or engage in lower effort, but from the lower participation of the population in the labor force. By 2009, income per capita had declined to $32 \%$ and productivity levels in Venezuela were around $40 \%$ of those in the US. Their conclusion is that lower total factor productivity and lower capital accumulation are at the root of the collapse of income in Venezuela. That is, that the massive 
proceeds of oil were largely misallocated. Note that contrary to the rest of Latin American countries in the period 1970-2010, Venezuela experienced a decline in GDP per-capita in absolute terms and not only vis-à-vis developed economies.

The sources of such notable stagnation are the focus and main contribution of the paper by Bello and co-authors. They disaggregate resource misallocation into three components. First, misallocation arising from the deliberate attempt of the government to move production away from oil and the limitations to private sector participation. Second, the massive misallocation of public funds to non-profitable investments following the 1974 oil price shock. Third, the direct market intervention in support of import-substitution and widespread price controls.

The authors develop a calibrated model of the Venezuelan economy based on Restuccia and Rogerson (2008) that allows them to study firm entry, employment and capital accumulation in an environment characterized by heterogeneity in productivity levels. They show first that high entry-costs in Venezuela - roughly six times higher than that in advanced economies - would reduce TFP by around $15 \%$ and output by $20 \%$ relative to an undistorted economy. This is a sizable effect in terms of lower productivity, wages and welfare but it falls very short of accounting for the distance between Venezuela and its US benchmark and, more importantly, it cannot account for lower capital accumulation or employment. Their second experiment, consisting of imposing a $40 \%$ tax on output to the $70 \%$ most efficient firms, can explain less of the decline in productivity but its describes properly the lower capital accumulation of the Venezuelan economy after 1975 and estimates the output sacrifice ratio in around $33 \%$. In their third and final experiment using the calibrated model they find that the combined policies of high entry costs and output taxes can account for over $90 \%$ of the observed differences in output between Venezuela and the US.

\subsection{Mexico}

All papers in this volume, as well as previous studies, point to the fact that growth rates in per-capita income during the period of import substitution were not markedly lower when compared to previous decades. Defendants of the import substitution strategy (ISS) adamantly exhibit these figures as evidence of sustained growth and structural transformation in the period as proof of its viability and success (e.g., Rodrik, 2000). The majority of scholars, however, are very critical 
of the ISS, pointing out the damaging consequences of protectionism, excess government intervention and price distortions (e.g., Bruton, 1998). The successful experience of export-oriented strategies in East Asian countries provides additional support to reject the ISS.

Few attempts have been made to understand why some Latin American countries performed relatively well under the ISS. In general, it is claimed that the first phases of import-substitution are "easy" but no quantitative support to such claim is provided. Timothy Kehoe and Felipe Meza attempt to provide a solid-grounded, quantitative answer as to why income per working-age person grew faster in Mexico during the period of ISS than after the massive market liberalization of the reforms in the 1990s. The empirical results suggest that in early stages of ISS, i.e. between 1950 and 1970, Mexico experienced significant catch-up growth as the result of three factors: (a) massive migration of workers from rural to urban sectors that provided an ample labor supply, (b) far-reaching government intervention that induced significant - though not necessarily cost-effective-industrialization with massive, and (c) an important process of accumulation of human capital that increased labor productivity. Economic growth in Mexico during the early ISS stages was also the result of the adverse effects of the Big Depression: by 1933, GDP per capita was around $40 \%$ below its long-run trend. Kehoe and Meza argue that these strategies had already been exhausted by the 1980s, around the time when the Mexico started its pro-market reforms.

Kehoe and Meza's theory is based on the notion that the useable stock of knowledge has increased very smoothly over the past century or more and that it can be adopted, perhaps at some cost, by countries that are behind the industrial leader. Such increase in knowledge induces, in equilibrium, a trend growth that they place at about two percent per year. However, the absolute level of income - measured as GDP per-working person - of a specific country relative to the industrial leader depends at any point in time on its institutions and economic policies. Changes in these institutions and key economic policies can cause depressions or booms. Eventually, however, if institutions and policies stabilize, and after capital and labor have adjusted, the country returns to trend growth. Mexico, as well as other countries in this volume, has had massive institutional shocks during the 20th century that have affected its income level, the ISS being a primary example (others include land reform and outbursts of political violence). Once the effects of such shocks have dissipated, Mexico as well as the other 
countries analyzed in this volume, have returned to trend and, not surprisingly, growth rates have returned to the long term benchmark.

\section{LESSONS AND OPEN QUESTIONS}

The papers in this volume tend to agree that Latin America's development problem is not one of factor accumulation, but of low productivity levels and anemic productivity gains. Empirical evidence collected by the authors suggests that physical capital and labor have not been a significant deterrent to economic growth. It is the misuse of such resources which is mainly to be blamed for the mediocre economic growth experienced throughout most of the independence period.

In particular, they agree that TFP growth has been retarded in many ways by a variety of wrong policy choices. Chiefly among wrong policies are the import substitution strategy in which all countries embarked following the Great Depression with varying degree of enthusiasm, the fiscal irresponsibility that characterized public decision-making in different episodes, and the widespread intervention of the State in investment as well as production decisions,. Collectively, they seem to have had significant costs in terms of growth. At the same time, the adequate economic policies can set the stage for private investment to flourish and foster productivity gains and sustained economic growth as the case of Chile since the mid-1980s-and Mexico more recently - suggests.

While most Latin American countries have suffered from the same malaise, the combination of external shocks and domestic policies and the timing of events in each country have been different. When trying to explain Latin America's disappointing development path, this indicates that there may be several alternative explanations and a variety of channels at work. In turn, this call for economists to provide models and measurements that can weigh the relative merits of each hypothesis using a suitable framework. The papers in this volume make a compelling case for the need to base future research in quantitative, general equilibrium models: simple yet powerful models allow for rigorous testing and open space for new interpretation of the events. The empirical results provide useful measurements but are yet to be considered preliminary and partial answers to the broad question of the failure of development in Latin America. The issue certainly invites further research. In particular, there is an obvious 
need for economists to find general explanations for the development problem from which the experience of each country would be but one realization. That would allow us to measure and compare the impact of each of these policies on factor accumulation, productivity gains and long run development.

Beyond the measurement of the impact of external shocks and policies on long run growth and productivity, there is the issue of why Latin America has been stuck for so long in making bad policy choices (from the growth perspective) without straightening itself, while other regions of the planet have been capable of selecting adequate policies from the start or otherwise correcting those policies that proved wrong (particularly in East Asia). This question relates most likely to political and sociological elements that would require extending and enriching our standard economic models along these dimensions. The cases of Argentina and Venezuela are particularly shocking in this regard: having reached the levels of income per capita of developed nations 100 or 50 years ago respectively, they lost almost everything they had achieved in comparative terms. These countries not only made the wrong choices in the past, but according to the papers in this volume seem to be in a path of deepening, confirming, and consolidating their mistakes.

Buera et al.'s (2011) as well as Bello et al's papers invite to further research and address the issue of why country leaders and politicians allowed and even fostered massive mismanagement of fiscal resources (from large budget deficits to poorly designed public investment projects). After all, unsustainable deficits and subsequent painful fiscal adjustments leading to economic turmoil had invariably been accompanied by dramatic political events that, one can argue, could have been easily anticipated. Modeling the interplay between the economic and political dimensions of economic policy is, perhaps, the necessary next step to provide a more comprehensive answer. 


\section{REFERENCES}

Acemoglu, D., S. Johnson and J.A. Robinson (2001), "The colonial origins of comparative development: An empirical investigation," American Economic Review 91(5): 1369-401.

Bello, O., J. Blyde and D. Restuccia (2011), "Venezuela's growth experience," Latin American Journal of Economics 48(2): 199-226.

Bergoeing, R., P. Kehoe, T. Kehoe, and R. Soto (2002), "A Decade Lost and Found: Mexico and Chile in the 1980s", Review of Economic Dynamics, 5:166-205.

Bruton, H.J. (1998), "A reconsideration of import substitution," Journal of Economic Literature 36 (2): 903-936.

Buera, F., G. Navarro and J.P. Nicolini (2011), "The Argentine economy after two centuries," Latin American Journal of Economics 48(2): 133-156.

Coatsworth, J. (2008), "Inequality, institutions and economic growth in Latin America," Journal of Latin American Studies 40: 545-569.

Edwards, S. (2009), "Forty years of Latin America's economic development: From the Alliance for Progress to the Washington Consensus", Working Paper 15190, National Bureau of Economic Research, Cambridge, MA.

Elías, V. (1992), Sources of growth. A study of seven Latin American economies, Fundación Tucumán and International Center of Economic Growth.

Engerman, S.L. and K.L. Sokoloff (1997), "Factor endowments, institutions, and differential paths of growth among New World economies: A view from economic historians of the United States," in S. Haber (ed.), How Latin America fell behind: Essays on the economic history of Brazil and Mexico, 1800-1914. Stanford.

Fuentes, R. (2011), "A unified growth model for independent Chile," Latin American Journal of Economics 48(2): 157-179

Hachette, D. (2011), Latinoamérica en el siglo XX: crecimiento, comercio y pensamiento económico. Ediciones UC: Santiago, Chile.

Hofman, A. (ed.) (2000), The economic development of Latin America in the Twentieth Century. Northampton, MA: Edward Elgar Publishing.

Lange, M., J. Mahoney and M. vom Hau (2006), "Colonialism and development: A comparative analysis of Spanish and British colonies," American Journal of Sociology 111(5): 1412-62.

Maddison, A. (2006), The World economy. Volume II: Historical statistics. Development Centre Studies, OECD.

Prescott, E. (1997), "Needed: A theory of total factor productivity," Staff Report Number 242, Federal Reserve Bank of Minneapolis.

Riascos, A.J. (2011), "Two hundred years of Colombian economic growth: The role of TFP," Latin American Journal of Economics 48(2): 181-198.

Rodrik, D. (2000), "Development strategies for the next Century," Annual World Bank Conference on Development Economics 2000, Fall 2001. 
Solimano, A. and R. Soto (2006), "Latin American economic growth in the late 20th. century: Evidence and interpretation", chapter 1 in Vanishing growth in Latin America, A. Solimano, (ed.), Edward Elgar Publishers.

Solow, R. (1956), "Technical change and the aggregate production function," Review of Economics and Statistics 39, 312-20, August.

World Bank (2001), Rethinking the East Asian miracle. J. Stiglitz and S. Yusuf (eds), Washington: DC.

World Bank (2011), World Development Indicators. Washington: DC. 